\title{
Studies on the Mode of Action of Cholera Toxin
}

\author{
EFFECTS ON SOLUBILIZED ADENYLATE CYCLASE
}

\author{
Barbara Beckman, Jorge Flores, Patricta A. Wrtkum, and \\ GeOFFrey W. G. SHARP \\ From the Department of Medicine, Massachusetts General Hospital, Boston, \\ Massachusetts 02114, and the Departments of Medicine and Physiology, \\ Harvard Medical School, Boston, Massachusetts 02115
}

\begin{abstract}
A в S T RACT To gain further insight into the mechanism of action of cholera toxin, solubilized preparations of adenylate cyclase from control and toxin-treated rat livers were studied. Adenylate cyclase activity was measured in both particulate and solubilized form in rat liver under control conditions and after intravenous injection of cholera toxin. Cholera toxin caused a 3.3fold activation of adenylate cyclase in the particulate preparation and a 5.8-fold increase in the solubilized preparation. Thus, the ability of cholera toxin to stimulate adenylate cyclase is present even when the enzyme membrane environment is disrupted. Furthermore, the solubilized enzyme, after treatment with cholera toxin, retained its ability to respond to catecholamines, but not to glucagon. In contrast, the control enzyme lost its responsiveness to catecholamines and glucagon after solubilization.
\end{abstract}

\section{INTRODUCTION}

Recent studies have shown that the diarrhea of cholera is due to stimulation of adenylate cyclase in the mucosal epithelial cells of the small intestine (1-5). The stimulation is caused by an exoenterotoxin of the cholera vibrio, a protein with a molecular weight of 84,000 (6). Increased concentrations of adenosine $3^{\prime}, 5^{\prime}$, monophosphate in the cells (7) results in increased body-to-lumen ion transport and consequent fluid production $(8,9)$. In previous studies on intestine, it has been shown that prostaglandin responsiveness is not affected by cholera

G. W. G. Sharp was supported by a Public Health Service Research Career Development Award of the National Institute of Arthritis and Metabolic Diseases, 1 Ko4 AM-42376.

Received for publication 17 October 1973 and in revised form 7 January 1974. toxin (2). In experiments on rat livers, it has been shown that the $\beta$-adrenergic responses to catecholamines and the response to the polypeptide hormone, glucagon, were unaffected. ${ }^{1}$ Thus, we have assumed that the effect of cholera toxin is not mediated by the receptors for prostaglandins, catecholamines or polypeptide hormones. In an attempt to further explore the action of cholera toxin, we have examined a solubilized preparation of adenylate cyclase from livers of rats treated with toxin.

\section{METHODS}

Female Sprague-Dawley rats, weighing 100-120 g, were injected with $1 \mu \mathrm{g} / \mathrm{g}$ of purified cholera toxin (10) into the jugular vein. Controls were injected similarly with an equal volume of Tyrode-Ringer solution $(\mathrm{NaCl}, 137 \mathrm{mM}$; $\mathrm{KCl}, 2.7 \mathrm{mM}$; $\mathrm{NaHCO}_{3}, 12 \mathrm{mM} ; \mathrm{NaH}_{2} \mathrm{PO}_{4}, 0.4 \mathrm{mM}$; $\mathrm{MgCl}_{2}, 0.5 \mathrm{mM} ; \mathrm{CaCl}_{2}, 1.8 \mathrm{mM}$; total solute concentrations $290 \mathrm{mosmol} / \mathrm{kg} \mathrm{H} \mathrm{H}_{2} \mathrm{O} ; \mathrm{pH} \mathrm{7.95).} 4 \mathrm{~h}$ after the injection of cholera toxin, the livers were perfused in situ through the portal vein with an ice-cold solution of $0.13 \mathrm{M}$ potassium chloride and $0.02 \mathrm{M}$ potassium acetate, $\mathrm{pH} 7.4$, to remove blood. $500-\mathrm{mg}$ portions of livers were weighed out; tissues were rinsed with $0.01 \mathrm{M}$ Tris- $\mathrm{HCl} \mathrm{Buffer}, \mathrm{pH}$ 7.4, placed in $5 \mathrm{ml}$ of a solution of $0.01 \mathrm{M}$ Tris- $\mathrm{HCl}, 0.25$ $\mathrm{M}$ sucrose, $0.001 \mathrm{M}$ EDTA- $\mathrm{MgCl}_{2}$, and homogenized by three strokes in a Dounce homogenizer. The homogenates were centrifuged for $10 \mathrm{~min}$ at $1,000 \mathrm{~g}$ at $4^{\circ} \mathrm{C}$. Pellets were resuspended in either an equal volume of the Tris$\mathrm{HCl}$ buffer (for the particulate preparation) or Tris- $\mathrm{HCl}$ buffer containing $0.25 \%$ Lubrol PX (for the soluble preparation). The particulate preparation was homogenized further by 20 strokes of the pestle in a Dounce homogenizer. The solubilized enzyme was prepared by subjecting the pellet to 40 strokes in a Dounce homogenizer. The mixture was then centrifuged at $200,000 \mathrm{~g}$ for $30 \mathrm{~min}$ in a Beckman L2-65 ultracentrifuge (Beckman Instruments Inc.,

\footnotetext{
${ }^{1}$ Sharp, G. W. G., P. Witkum, B. Beckman, and J. Flores. Studies on the mode of action of cholera toxin: adenylate cyclase and interaction with hormone receptors. Biochim. Biophys. Acta. In press.
} 
TABLE I

Adenylate Cyclase Activity in Particulate and Solubilized Enzyme Preparations

\begin{tabular}{cccccc}
\hline & Basal* & Toxin & Fluoride & $\Delta$ & $P$ \\
\hline Particulate $\neq$ & $\mathbf{8 1 \pm 8 \S}$ & $270 \pm 23$ & & +189 & $<0.001$ \\
& $\mathbf{8 1 \pm 8}$ & & $455 \pm 36$ & +374 & $<0.001$ \\
& & $270 \pm 23$ & $412 \pm 28$ & +142 & $<0.001$ \\
Solubilized $\neq$ & $\mathbf{8 4} \pm 10$ & $485 \pm 43$ & & +401 & $<0.001$ \\
& $\mathbf{8 4} \pm 10$ & & $301 \pm 23$ & +217 & $<0.001$ \\
& & $485 \pm 43$ & $471 \pm 43$ & -14 & NS \\
\hline
\end{tabular}

* Adenylate cyclase activity expressed as pmol cyclic AMP $\cdot(m g \text { protein })^{-1}$ $\cdot(10 \mathrm{~min})^{-1}$.

$\ddagger n=13$.

\&alues represent the mean $\pm \mathrm{SEM}$.

Spinco Div., Palo Alto, Calif.). The supernate containing the solubilized adenylate cyclase was stirred with an equal volume of resin (Amberlite XAD-2, Mallinckrodt Chemical Works, St. Louis, Mo.), equilibrated with $0.01 \mathrm{M}$ Tris- $\mathrm{HCl}$ buffer, $\mathrm{pH} 7.5$, for $30 \mathrm{~min}$ at $4^{\circ} \mathrm{C}$ to adsorb the Lubrol. To remove Amberlite, the resin-supernate mixture was centrifuged at $1,000 \mathrm{~g}$ for $3 \mathrm{~min}$; the supernate was used for assay of adenylate cyclase. The protein content of the homogenate was determined by the method of Lowry, Rosebrough, Farr, and Randall (11) and diluted to the required protein concentration for enzyme assays.

Adenylate cyclase activity was determined by the method of Krishna, Weiss, and Brodie (12). $20 \mu 1$ of the liver homogenate (20-40 $\mu \mathrm{g}$ of protein) was added to $30 \mu \mathrm{l}$ of incubation mixture containing $1 \mu \mathrm{Ci}$ of $\left[\alpha^{32} \mathrm{P}\right] \mathrm{ATP}$ and incubated at $37^{\circ} \mathrm{C}$ for $10 \mathrm{~min}$. The final composition of the incubation mixture was: Tris- $\mathrm{HCl}$ buffer, $4 \mathrm{mM}(\mathrm{pH}$ 7.5); cyclic AMP, $0.1 \mathrm{mM}$; ATP, $0.1 \mathrm{mM}$; $\mathrm{MgCl}_{2}, 10$ $\mathrm{mM}$; phosphoenolpyruvate, $5 \mathrm{mM}$; pyruvate kinase, 0.07 $\mathrm{IU}$; and myokinase, 0.7 IU (reagents obtained from Sigma Chemical Co., St. Louis, Mo.). These were determined as the optimal conditions for the assay. Reaction blanks for each set of experiments were estimated in the absence of homogenate.

To terminate the reaction, $1 \mathrm{ml}$ of a cold solution containing $100 \mu \mathrm{g}$ cyclic AMP and $200 \mu \mathrm{g}$ ATP was added. Cyclic $\left[{ }^{3} \mathrm{H}\right] A M P$ was also added for calculation of recovery. After addition of this solution, the tubes were kept cold by placing them on ice. Tube contents were pipetted onto $0.6 \times 4.0-\mathrm{cm}$ chromatographic columns which had been prepared by pipetting $2 \mathrm{ml}$ of a $50 \%$ (vol/vol) aqueous suspension of Bio-Rad resin (AG-50W-X2, 200400 mesh, $\mathrm{H}^{+}$form [Bio-Rad Laboratories, Richmond, Calif.]) into tubes containing glass wool supports. The cyclic AMP was eluted by water in the 4th and 5 th $\mathrm{ml}$. Impurities in this fraction were removed by two precipitations with $0.25 \mathrm{M} \mathrm{ZnSO}$, and $0.25 \mathrm{M} \mathrm{Ba}(\mathrm{OH})_{2}$, care being taken that the final $\mathrm{pH}$ of the solution was close to 7.5. After centrifugation for $5 \mathrm{~min}$ at $1,000 \mathrm{~g}$ the precipitation was repeated. Then the supernate was transferred to scintillation vials containing $15 \mathrm{ml}$ of a naphthalene-dioxane solvent system. ${ }^{8} \mathrm{H}$ and ${ }^{32} \mathrm{P}$ were estimated simultaneously in a liquid scintillation spectrometer. $\mathrm{Re}-$ covery of cyclic AMP, as estimated with cyclic $\left[{ }^{3} \mathrm{H}\right] \mathrm{AMP}$, was $50-70 \%$. The amount of cyclic AMP formed was calculated from the specific activity of $\left.{ }^{32} \mathrm{P}\right] \mathrm{ATP}$ in the incubation mixture and the amount of cyclic $\left[{ }^{8} \mathrm{H}\right] A M P$ recovered minus reaction blank. The reaction blank is always less than $10 \%$ of the basal adenylate cyclase activity. Re- sults are expressed in picomoles of cyclic AMP per milligram of protein per unit of time.

Purified cholera toxin was prepared under contract for the National Institute of Allergy and Infectious Diseases by R. A. Finkelstein, Ph.D., The University of Texas Southwestern Medical School, Dallas, Tex. Lubrol PX was supplied by ICI America, Inc., Wilmington, Del. Adenosine $5^{\prime}-\left[\alpha{ }^{32} \mathrm{P}\right]$ triphosphate trisodium salt (sp act $1-5 \mathrm{Ci}$ $\mathrm{mM}$ ) was obtained from International Chemical and $\mathrm{Nu}$ clear Corporation, Burbank, Calif.; [8- $\left.{ }^{8} \mathrm{H}\right]$ adenosine $3^{\prime}, 5^{\prime}$ cyclic monophosphate (sp act approximately $16 \mathrm{Ci} / \mathrm{mM}$ ) from Schwartz/Mann Div., Becton, Dickinson and Co., Orangeburg, N. Y.

\section{RESULTS}

Table I presents the results of 13 experiments in which the effect of cholera toxin on the activity of a particulate preparation of adenylate cyclase in rat livers was measured. Cholera toxin activated the adenylate cyclase in each animal, with an average increase of 3.3-fold over the control value. Solubilized adenylate cyclase preparations from the same rats also showed the activating effect of cholera toxin. Solubilized control cyclase activity was $84 \mathrm{pmol}$ cyclic AMP/mg protein per $10 \mathrm{~min}$ relative to 81 for the particulate preparation. Solubilized cyclase from toxin-treated animals was 485 $\mathrm{pmol}$ cyclic AMP $/ \mathrm{mg}$ protein per 10 min relative to 270 for the toxin-treated particulate preparation. Thus, the solubilized enzyme in control animals had a specific activity equal to the particulate preparation, while the solubilized enzyme for toxin-treated liver had a significantly greater specific activity than that for the control.

Fluoride $\left(10^{-2} \mathrm{M}\right)$ stimulated adenylate cyclase activity in both control and toxin-treated particulate preparations. The level of activity achieved was not significantly different under the two conditions, although the increment in activity due to fluoride was less in the toxin-treated tissues. That is to say, the stimulation due to the toxin overlapped that of the fluoride. In the solubilized preparation, fluoride stimulated the control enzyme activity, but the level of activation was considerably less than that achieved by cholera toxin alone. When the toxin-stimulated enzyme was treated with fluoride, no further stimulation of enzyme activity was seen.

In the particulate preparation, epinephrine $\left(10^{-4} \mathrm{M}\right)$, isoproterenol $\left(10^{-4} \mathrm{M}\right)$, and glucagon $\left(2 \times 10^{-6} \mathrm{M}\right)$ all stimulated adenylate cyclase in both control and toxinstimulated preparations (Table II). Furthermore, a significant enhancement of the responses to epinephrine and isoproterenol was observed as a result of toxin treatment. For control tissue, the increments were 26 and $19 \mathrm{pmol} / \mathrm{mg}$ protein per $10 \mathrm{~min}$, respectively, while for toxin-treated tissues, the increments were 85 and 62 , respectively. The response to glucagon was quantitatively the greatest stimulation observed, the increments in ac- 
tivity being $171 \mathrm{pmol} / \mathrm{mg}$ protein per $10 \mathrm{~min}$ in the control and $126 \mathrm{pmol} / \mathrm{mg}$ protein per $10 \mathrm{~min}$ in the toxin-treated preparation. These two values were not significantly different.

In the solubilized control adenylate cyclase preparation, all tested hormone responsiveness was lost (Table II). However, when the hormonal responses of the toxin-treated soluble enzyme were examined, a surprising retention of sensitivity to catecholamines was found. Epinephrine and isoproterenol both stimulated the solubilized adenylate cyclase. In contrast, glucagon, which had a large effect in the particulate preparation, was without effect upon the solubilized toxin-treated enzyme (Table II).

\section{DISCUSSION}

In previous studies on the mode of action of cholera toxin, it has been found that the toxin is taken up rapidly by cells and then causes a progressive increase in adenylate cyclase activity (8). Furthermore, the stimulation appears to be permanent and cannot be removed by extensive washing of the membranes (3). The stimulatory effect is presumed to be indirect, in that the brush border membranes of the cells of the small intestine, the presumed site of uptake (13), do not contain adenylate cyclase (14). Thus, it seemed that translocation of the toxin might occur after uptake or that progressive changes in the cell membrane might alter a restraining environment in which adenylate cyclase functioned.

It has been found that the responses to catecholamines and glucagon can still be obtained after treatment with toxin and that the stimulation achieved was similar in control and toxin treated tissues. ${ }^{1}$ In the study reported here, the responses to epinephrine and isoproterenol by the particulate preparation were significantly enhanced by cholera toxin. The significance and mechanism of the enhancement is unknown.

As a further exploration of the action of cholera toxin, we have studied solubilized adenylate cyclase and found that the stimulatory effect of the toxin is still present. This suggests an action directly on the adenylate cyclase complex. Whether this represents direct binding of the toxin to adenylate cyclase after translocation in the cell, or perhaps a toxin-ganglioside interaction with the enzyme complex, as has been suggested (15, $16)$, remains to be determined.

A surprising finding was that the solubilized toxintreated enzyme was still responsive to stimulation by catecholamines. With one exception (17), solubilized adenylate cyclase from normal tissues has been found unresponsive to hormones, despite the presence of receptors (18). Also, after solubilizing turkey erythrocyte membranes with Lubrol PX, catecholamine-specific binding was still present, although adenylate cyclase ac-
TABLE II

Effects of Hormones on Adenylate Cyclase Activity

\begin{tabular}{|c|c|c|c|c|c|}
\hline & $\begin{array}{c}\text { Epine- } \\
\text { phrine, } \\
1 \times 10^{-4} \\
\mathrm{M}\end{array}$ & $\begin{array}{c}\text { Isopro- } \\
\text { terenol, } \\
1 \times 10^{-4} \\
\mathrm{M}\end{array}$ & $\begin{array}{c}\text { Glucagon, } \\
2 \times 10^{-6} \\
M\end{array}$ & $\Delta \pm \mathrm{SEM}$ & $P$ \\
\hline \multicolumn{6}{|c|}{ Particulate rat liver preparation* } \\
\hline \multicolumn{6}{|l|}{ Basalł } \\
\hline $81 \pm 8 \S$ & $107 \pm 13$ & & & $26 \pm 10$ & $<0.05$ \\
\hline $81 \pm 8$ & & $100 \pm 10$ & & $19 \pm 6$ & $<0.01$ \\
\hline $81 \pm 8$ & & & $252 \pm 14$ & $171 \pm 12$ & $<0.001$ \\
\hline \multicolumn{6}{|l|}{ Toxin } \\
\hline $270 \pm 23$ & $354 \pm 28$ & & & $85 \pm 3$ & $<0.001$ \\
\hline $270 \pm 23$ & & $332 \pm 30$ & & $62 \pm 12$ & $<0.001$ \\
\hline $270 \pm 23$ & & & $396 \pm 35$ & $126 \pm 17$ & $<0.001$ \\
\hline \multicolumn{6}{|c|}{ Solubilized rat liver preparation* } \\
\hline \multicolumn{6}{|l|}{ Basal } \\
\hline $84 \pm 10$ & $81 \pm 6$ & & & $-3 \pm 7$ & NS \\
\hline $84 \pm 10$ & & $76 \pm 5$ & & $-8 \pm 6$ & NS \\
\hline $84 \pm 10$ & & & $80 \pm 6$ & $-4 \pm 5$ & NS \\
\hline \multicolumn{6}{|l|}{ Toxin } \\
\hline $485 \pm 43$ & $523 \pm 51$ & & & $+38 \pm 14$ & $<0.05$ \\
\hline $485 \pm 43$ & & $542 \pm 58$ & & $+57 \pm 24$ & $<0.05$ \\
\hline $485 \pm 43$ & & & $488 \pm 43$ & $+3 \pm 8$ & NS \\
\hline
\end{tabular}

$* n=13$.

$\ddagger$ Adenylate cyclase activity expressed as pmol cyclic AMP $\cdot(\text { mg protein })^{-1}$ $\cdot(10 \mathrm{~min})^{-1}$.

$\S$ Values represent the mean $\pm \mathrm{SEM}$.

tivation by catecholamines was lost (19). For responsiveness to be restored, it appears that specific phospholipids are required (20). The hormone sensitivity after treatment with cholera toxin suggests that the hormone receptors can still combine with the adenylate cyclase or are still combined, perhaps being protected from the effect of Lubrol treatment by the cholera toxin. The maintenance of catecholamine sensitivity appears to be a phenomenon specific for the $\beta$-adrenergic receptors, since the ability to respond to glucagon was lost.

The effects of fluoride on adenylate cyclase under these conditions are complex. It has been found previously that the level of activity achieved in particulate preparations of intestinal cells in the presence of cholera toxin and fluoride is similar to that of fluoride alone (2, 4 ), i.e., the effects were overlapping. In two other studies, however, the effect of cholera toxin and fluoride was found to be greater than that of fluoride alone $(1,5)$, although not completely additive. In this study, the former has been found to be the case; thus, the fluoride ion effect overlaps that of the cholera toxin. In the case of the solubilized enzyme, no such additivity was apparent.

A series of conclusions can be drawn from this work: the effect of cholera toxin is apparent on adenylate cyclase even after solubilization by Lubrol PX; thus, the effect may be directly on the enzyme, since modification of membrane structure by the detergent does not re- 
sult in disappearance of the toxin effect; furthermore, the action of cholera toxin protects the catecholamine sensitivity of the enzyme during solubilization. Studies are in progress to determine whether the toxin is bound to the solubilized adenylate cyclase.

\section{ACKNOWLEDGMENTS}

This work was supported in part by grants from the John A. Hartford Foundation, Inc., and by the Public Health Service research grants HE-06664 from the National Heart Institute and AM 04501 from the National Institute of Arthritis and Metabolic Diseases.

\section{REFERENCES}

1. Kimberg, D. V., M. Field, J. Johnson, A. Henderson, and E. Gershon. 1971. Stimulation of intestinal mucosal adenyl cyclase by cholera enterotoxin and prostaglandins. J. Clin. Invest. 50: 1218.

2. Sharp, G. W. G., and S. Hynie. 1971. Stimulation of intestinal adenyl cyclase by cholera toxin. Nature (Lond.). 229 : 266.

3. Sharp, G. W. G., S. Hynie, L. C. Lipson, and D. Parkinson. 1971. Action of cholera toxin to stimulate adenyl cyclase. Trans. Assoc. Am. Physicians Phila. 84: 200.

4. Chen, L. C., J. E. Rohde, and G. W. G. Sharp. 1971. Intestinal adenyl cyclase activity in human cholera. Lancet. 1 : 939.

5. Sharp, G. W. G., S. Hynie, H. Ebel, D. H. Parkinson, and P. Witkum. 1973. Properties of adenylate cyclase in mucosal cells of the rabbit ileum and the effect of cholera toxin. Biochim. Biophys. Acta. 293: 1.

6. LoSpalluto, J. J., and R. A. Finkelstein. 1972. Chemical and physical properties of cholera exo-enterotoxin (choleragen) and its spontaneously formed toxoid (choleragenoid). Biochim. Biophy's. Acta. 257: 158.

7. Schafer, D. E., W. D. Lust, B. Sircar, and N. D. Goldberg. 1970. Elevated concentration of adenosine $3^{\prime}$ : $5^{\prime}$-cyclic monophosphate in intestinal mucosa after treatment with cholera toxin. Proc. Natl. Acad. Sci. U. S. A. $67: 85$.
8. Guerrant, R. L., L. C. Chen, and G. W. G. Sharp. 1972. Intestinal adenyl cyclase activity in canine cholera: correlation with fluid accumulation. J. Infect. Dis. 125 : 377.

9. Pierce, N. F., C. C. J. Carpenter, Jr., H. L. Elliot, and W. B. Greenough, III. 1971. Effects of prostaglandins, theophylline and cholera exotoxin upon transmucosal water and electrolyte movement in the canine jejunum. Gastroenterology. 60: 22.

10. Finkelstein, R. A., and J. J. LoSpalluto. 1970. Production of highly purified choleragen and choleragenoid. J. Infect. Dis. 121 (Suppl.) : 463.

11. Lowry, O. H., N. S. Rosebrough, A. L. Farr, and R. J. Randall. 1951. Protein measurement with the folin-phenol reagent. J. Biol. Chem. 193: 265.

12. Krishna, G. B., B. B. Weiss, and B. B. Brodie. 1968. A simple sensitive method for the assay of adenyl cyclase. J. Pharmacol. Exp. Ther. 163: 379.

13. Peterson, J. W., J. J. LoSpalluto, and R. A. Finkelstein. 1972. Localization of cholera toxin in vivo. $J$. Infect. Dis. 126: 617.

14. Parkinson, D. K., H. Ebel, D. R. DiBona, and G. W. G. Sharp. 1972. Localization of the action of cholera toxin on adenyl cyclase in mucosal epithelial cells of rabbit intestine. J. Clin. Invest. 51: 2292.

15. Van Heyningen, W. E., C. C. J. Carpenter. N. F. Pierce, and W. B. Greenough, III. 1971. Deactivation of cholera toxin by ganglioside. J. Infect. Dis. 124: 415.

16. Cuatrecasas, P. 1973. Gangliosides and membrane receptors for cholera toxin. Biochemistry. 12: 3558.

17. Neer, E. J. 1973. Vasopressin-responsive, soluble adenylate cyclase from the rat renal medulla. J. Biol. Chem. $248: 3742$.

18. Lefkowitz, R. J., E. Haber, and D. O'Hara. 1972. Identification of the cardiac $\beta$-adrenergic receptor protein: solubilization and purification by affinity chromatography. Proc. Natl. Acad. Sci. U. S. A. 69: 2828.

19. Bilezikian, J. P., and G. D. Aurbach. 1973. A $\beta$ adrenergic receptor of the turkey erythrocyte. I. Binding of catecholamines and relationship to adenylate cyclase activity. J. Biol. Chem. 248: 5577.

20. Levey, G. S. 1971. Solubilization of myocardial adenyl cyclase: Loss of hormone responsiveness and activation by phospholipids. Ann. N. Y. Acad. Sci. 185: 449. 